\title{
Zarqa University Interesting in Quality of its Services Provided to the Local Community from the Perspective of their Employees
}

\author{
Dr. Majid Abdul-Mahdi Mesaadah
}

Faculty of Economics and Administrative Sciences / Zarqa University

\begin{abstract}
This study aimed to study the interest of Zarqa University in quality of its services provided to the local community from the perspective of there employees. To achieve this purpose was to build and develop a questionnaire consisted of (45) items, were then test the sincerity of the tool and its reliability, and was applied at the study sample of (98) teaching staff and administrative, was chosen randomly from the population of (580) teaching staff and administrative, by using the stratified random sample. The study finding a number of results, including: there were no statistically significant differences at the significance level $(\alpha=0.05)$, between the responses of the staff in Zarqa University about the quality of services provided to the local community, attributable to some personal and functional characteristics as (gender, specialization of college, academic qualification, and experience years).
\end{abstract}

Keywords: Quality of services, Local community, Zarqa University, Jordan.

\section{INTRODUCTION}

The higher education occupy interest of the governments, institutions and individuals, because of its importance in shaping the future paths of the nations and communities, and the importance have increased in the light of what posed the globalization of the concepts and applications and enhance the rapid development of the communication and information systems. It has resulted in a pivotal shifts toward adapting to what is called the information society and the global knowledge, and moved the compete which witnessed the global markets between the companies to higher education institutions, competition from a new type its pivot the innovation and the evolution as a means to get the highest returns (Mattawaa, 2000).

The success of these universities in the process of competition in the third millennium that is associated with the quality and qualitative in education, the ability to transfer what we learn to the products or services that can compete, through the university's response to the needs of their communities, including making work sites and production an arena to use education and apply the knowledge is reflected on the their creative capabilities and its growth and development (An-Najjar, 2000).

And the size and quality of university services is associated with the management system that make the mission of the university compass of movement on the road of the guiding principles and the undergraduate ethics, and so we see that the university performance level will not rise without orientation to the modern management concepts such as: the concept of total quality management (TQM), which is considered of the most modern management techniques success in recent years, has been achieved in the industrial, health, social, and educational sectors in a lot of nations in the developed world (Dradkeh, 2004).

As the administration's success is associated with the productivity efficient, so popping the total quality management (TQM) to achieve rise the productivity and continuity the quality, and became the total quality management integrated strategy for the development of the productive and service institutions, including the educational institutions, because they management focuses on performing the work correctly, and in a typical manner and ideal avoids waste of resources or its misuse, and reduce of disputes between employees and the satisfaction of the beneficiaries, supports the innovation and renewal (Hariand, 2001).

The concern of quality control in the educational institutions of the stemmed to look at the education as a commodity must have to compete and seek to satisfy the consumers of that commodity from the 
students and the community and the state. Students wishing to obtain the best qualifications for the job opportunities increasingly scarce increase in the number of graduates and the lack of employment opportunities, and parents of the students aspire to a better qualifying of their sons, and the state they aspires to distinct learning outcomes enable them to achieve the objectives of its development plans (Barakat, 2003).

The concept of Total Quality Management in higher education involves performing directing of all academic activities and operations, administrative, financial, and at all levels in the higher education system to satisfy the desires of labor market and student, through continuous development and improvement for the quality of service provided to students in order to get a graduate with high efficiency required by the labor market, by creating a new organizational culture based on the commitment to the principle of routing customer (students and the labor market), and the management commitment to continuous improvement and principle of collective participation, and evaluate appropriate of all academic, administrative and financial situations in conformity with the entrance of Total Quality Management (Shiraz, 2003).

Witnessed subject of the quality interest sophisticated and widespread in Morocco since World War II until now, has stimulated such a development many of them government laws and acceleration technology and increase the production and intensification of domestic and international competition, and the truth factors that increased competition was the main factor for the intensification of businesses to the crisis, which has sought to get out of sharp price competition and the direction of creating a competitive advantage over their competitors and ensure its proper share of the market, hence the trend of excellence for the quality which led to the development of concepts and methods of quality.

It is axiomatic that university education can not achieve its objectives in the economic and social development if its situation are unstable, and methods are unable to meet the labor market needs, so the concern the quality of university education system by all its elements is of paramount importance should in the university departments that attaches the greatest attention, the entrance of the total quality includes several management ideas, and agree to a large extent with the substantive values, it aims to satisfy the student, community, and the development of openness and trust and of teamwork, continuous and progressive improvement, and attention to the incentives to induce greater productivity, the introduction, generally, the application of the quality management in the universities requires faith and support of senior management, and change the logic of the prevailing organizational relations, including removing impediments creativity, and the creation of the administrative organization of the activity of the quality in the university and ensure its sustainability, and taking into account the student's privacy in the application of the principle of external customer satisfaction in addition to taking into account the fact that the institutions of society beneficiary of graduates are external customers to universities (Bdh, 2003).

The university function is not limited to education and scientific research only in spite of its importance, the function of community service aspects include further than that, and can be referred to the forms of services provided by the community, such as: Append faculty members as advisers and experts in sites work and various production, and training the employees in the different society sectors in the university corridors to increase their abilities and their productivity, and to link the acceptance in the universities with the community needs in order to provide scientific and technical skills, quality and quantity (Hariand, 2000).

As the University has qualified local talent and trained scientifically and technically, they are able to offer their services and their experiences in several areas, such as continuing education through various programs and courses for the community and for nominal fees, and to provide appropriate scientific and technical consulting to various institutions of society, and to provide other services, as preparation the software, in addition to make way to use the university resources and services to meet simple wages (Aly, 2001).

Also, for the university active complimentary, the first goal is to community service, if you provide expertise and services a variety of medical, agricultural, engineering, social and sports fields for areas surrounding of the university, so the formation of a team of faculty members and student, to provide various services, contribute to development of skills and the behavioral attitudes for students with directly related to the fundamentals of their specialties, also contribute to increase the experience of faculty members and inform them of the society problems, and employ them in their lectures and their practical and theoretical researches(drunk,2003). 
And the university as a social institution affects on the social atmosphere surrounding it and affected by it, they are making the technical, professional and intellectual leaders, to be that each university is its role in the performance of the community service, education is the university in the atheist and the twentieth century should be based on the merger in the university community and fulfill its role through provide high services to wider slice from the society in order to achieve the undesirable changes lead to the growth and progress of the society (Rashid, 2005).

\section{MeThodologY}

\subsection{The Study Problem and Its Questions}

From where the awareness of the education role in the sustainable human development, has become the education quality of the important issues that have received care increased in recent times by the concerned higher education in different countries, due to increasing the pressure and criticism, which sector faced by this, it is still below the level of ambitions and efforts to support the overall activities of the state, and led to the emergence of a strong direction aims at pursuit to improve the efficiency of the education system, through the total quality of the outcomes of the education system to improve, and the commitment in the social responsibility for university towards the community in which it operates, by doing activities as significant contribution for the community.

In light of the foregoing, the study problem can be summarized in the following two questions:

a. What Zarqa University interesting in quality of its services provided to the local community from the perspective of their employees?

b. Is there exist differences between the employees responses in Zarqa University about the quality of services provided to the local community according to some personal and functional characteristics of (gender, specialty of faculty, qualification, and experience years).

\subsection{The Study Importance}

The study importance emanate of the vital theme which is the quality of community service, which is a development tool in the community, and a means renaissance industry, especially the quality in the local community service ensure has become a means to make sure the achievement of the educational system of the objectives laid down, and then focused the study importance to clarify the role importance played by the total quality standards in educational institutions and development institutions, even those so that it can prepare qualified staff able to meet the needs of society and its development.

\subsection{The Study Objectives}

This study seeks to achieve a number of the objectives are the following:

a. Identify the reality of the services provided to the local community by Zarqa University.

b. Measuring the differences between the employees responses in Zarqa University about the quality of its services provided to the local community according to some personal and functional characteristics of (gender, specialty of faculty, qualification, and experience years).

\subsection{The Study Hypotheses}

To achieve the study objectives, the researcher formulating the following hypothesis, as a null hypothesis $\left(\mathrm{H}_{0}\right)$ and are as follows:

$\mathbf{H}_{0}$ : There is no statistically significant differences at the significance level $(\alpha \leq 0.05)$, between the employees responses in Zarqa University about quality of its services provided to the local community attributable to some personal and functional characteristics of (gender, specialty the college, qualification, and experience years).

And emanate from the study hypothesis a number of sub-hypotheses are:

$\mathbf{H}_{\mathbf{0 1}}$ : There is no statistically significant differences at the significance level $(\alpha \leq 0.05)$, between the employees responses in Zarqa University about quality of its services provided to the local community attributable to (gender).

$\mathbf{H}_{\mathbf{0 2}}$ : There is no statistically significant differences at the significance level $(\alpha \leq 0.05)$, between the employees responses in Zarqa University about quality of its services provided to the local community attributable to (specialty the college). 
$\mathbf{H}_{03}$ : There is no statistically significant differences at the significance level $(\alpha \leq 0.05)$, between the employees responses in Zarqa University about quality of its services provided to the local community attributable to (qualification).

$\mathbf{H}_{04}$ : There is no statistically significant differences at the significance level $(\alpha \leq 0.05)$, between the employees responses in Zarqa University about quality of its services provided to the local community attributable to (experience years).

\subsection{Sources of Data Collection}

The study relied on two main sources of data collection are:

a. Primary Data: The data collection represented by a questionnaire was prepared and distributed to respondents, and included (45) items to measure bearings of faculty members towards the university's role in the local community service.

b. Secondary Data: The data collecting of this type it was by reference to the theoretical studies, books, references, articles, and the scientific researches which published in the Journals and periodicals.

\subsection{Previous Studies}

- Study of (Al-Tall and Sarayreh, 2013): This study aimed to identify the degree of interest to the quality of Mutah University of its role in serving the local community in the light of the estimates of the faculty, and to detect the impact of taxonomic study variables in these estimates. To achieve these objectives were applied a questionnaire consisted in its final form of (36) items were divided into three fields and then applied to a sample of (221) faculty member. The study found that the faculty members at Mutah University appreciate the interest of the quality of their university role in serving the local community (medium) degree, also there exist a statistically significant differences between the means of these estimates attributable to impact of the faculty status in the field of (university's reputation) in favor of the scientific faculties, and the impact of academic rank in the field of (Interacting with the community, and university's reputation) and all fields in favor of the rank (professor), while the study found there is no a statistically significant differences between the means of the estimates attributable to impact of faculty status in the two fields of (University policy toward the relationship in the community, and Interacting with the community) and all fields, also for impact of academic rank in the field of (University policy toward the relationship in the community), and impact of (experience in university teaching) field in each of the fields and in all fields.

- Study of (Ar-Rawashdeh, 2011): This study aimed to identify the role of Al-balqa Applied University in the community service, and to achieve the study objectives applied a questionnaire on a sample consisted of all faculty members in the faculty of Ajloun University. The study results showed that the role of the university in the community service was (median) importance, also these results showed there exist a statistically significant differences in their perspectives about the role of the university in the community service attributable to (sex) in favor of (females), and the (experience years) variable in favor of the age class (10 years and more), and the (academic rank) variable in favor of the (Assistant Professor).

- Study of (Ar-Rasheed, 2005): This study aimed at investigating the statement of the role of Jordanian universities in the community service, and to achieve this objective the study was applied a questionnaire on a sample consisted of all the faculty members and the employees at Jordanian Universities. The study results showed that the faculty members and the employees at Jordanian Universities appreciate the role of their universities of the community service in a (medium) degree, also these results showed that there were no statistically significant differences between the means of there estimates for the degree of the universities role in the community service attributable to the job title, and the university type.

- Study of (Yasien, 2003): This study aimed at investigating to know the reality and the future of the community service centers and continuing education in the Palestinian universities at the provinces of the north of Palestine (and their reality, their problems, and their future), the study sample consisted of the employees, trainers and trainees in the community service centers and continuing education at universities in the north of Palestine of (2165). The study concluded that there were differences in fields of the programs objectives, training, and planning for the programs and courses between males 
and females in the degree of the reality of the future of community service and continuing education centers in the Palestinian universities in favor of females, while there were no differences are a function of the fields of the organization for the programs and courses and the future of the centers and the total score. Also there were statistically significant differences for the degree of the reality and the future of the community service and continuing education centers in the Palestinian universities from the perspective of trainees attributable to the university variable and so on all fields.

- Study of (Ja'd, 2002): This study aimed at evaluating the reality of units of Community service and Continuing Education of the General Organization for the Technical Education and the Vocational training in Saudi Arabia, and to achieve this objective the study were applied a questionnaire on a sample consisted of (459) trainees and 174 trainers and (47) unit's Manager and employees. The study results showed that most of the units programs community service and continuing education geared to specific categories of the programs, and that its approach in the evaluation of its programs is the referendum method directed to the trainees, and there exist of weakness in the marketing process, and there were no a specific plan going on, and the lack of program planning in the light of the identification of members of the community training needs. As the house of these results and difficulties for these units hinder define its objectives, including poor coordination with other institutions to know their training needs, and inadequate allocated for training courses periods, and lack of appropriate training for the trainees time, and the lack of most of the programs "entitled Technical College the role of neighborhoods Saudi Arabia to the extent to which of the programs center of the community service and continuing education to the needs of the local community from the perspective of teaching members for the practical side, and their non-compliance with the professional or scientific level of the trainees, and weakness of the coaches level.

- Study of (Taimyu- Baily, 2001): This study aimed to define by the community services for colleges and the role of harmonization between the university and the community in it, the study revealed the results of a response (24) and agency for the services on the survey, which was about the services provided for adults, showed that the employees in these agencies did not have perceptions of negative about the cooperation between the university and the community in providing these services, but they did not realize how this cooperation between the university and the community. How could this cooperation can improve the services in light of the demand increasing dates back to anagen trends and the increase in population and the conclusion which understand from this study to: that the university can provide the services in light of the increase in the population number. The community which is a service to the community and to improve their conditions.

- Study of (Schumaker \& wood, 2001): This study aimed to identify on role of the University College of the community service in light of the experience of Nebraska faculty. A highlight of the study findings provide views can be tapped in light of the experience that thirty-year period of what made by the faculty of the University of Nebraska to provide the community services in public affairs and the community development, and showed that this distinct faculty supported the research, the participants in the community, and so this has succeeded the faculty with the help of university configures part of the community and the main conclusion of this study is that the faculty role in the activation of the university and help it to be part of the community, and the commitment in its role in his service and scalability.

- Study of (Basinger, 2000): This study aimed to recognize the reality of the contribution of the Mississippi University in providing services for the surrounding schools through a project fight against illiteracy in the state, the study results showed that the creation of such projects dates back a large benefit for students, and showed the importance of support the private sector for such projects adopted or are created in universities of the various States.

\section{Method And Procedures}

\subsection{The Study Approach}

The study used the descriptive and analytical approach to accomplish this study, and was used the descriptive method to describe the role of Zarqa University of local community service from the perspective of faculty members and administrators in, also been used as the analytical method to measure the differences between the employees responses in Zarqa University about quality of services provided to the local community according to some of the personal and functional characteristics of (Sex, specialty of faculty, academic qualification, experience years). 


\subsection{The Study Population and its Sample}

The study population consists of all faculty members and administrator whom are working at Zarqa University of (580) faculty member and administrator. And the study sample consists of (145) faculty member and administrator, selected according to stratified random sample method, with (25\%) from the population. After that the researcher distributed (145) questionnaire on the study sample, were returned (112) questionnaire, where the percentage of questionnaires returned is (87.5\%), and after review and audit questionnaires returned, were excluded (14) questionnaires for not expire because of lack of the information contained in each, and thus the number of valid questionnaires for the statistical analysis (98) questionnaire.

Table1. The study population and its sample, distributed questionnaires number, and valid questionnaires

\begin{tabular}{|c|c|c|c|c|c|c|}
\hline The Profession & $\begin{array}{c}\text { Population } \\
\text { Size }\end{array}$ & $\begin{array}{c}\text { Sample } \\
\text { Size }\end{array}$ & $\begin{array}{c}\text { Distributed } \\
\text { Questionnaires }\end{array}$ & $\begin{array}{c}\text { Retrieved } \\
\text { Number }\end{array}$ & $\begin{array}{c}\text { Valid } \\
\text { Number }\end{array}$ & $\begin{array}{c}\text { Valid } \\
\text { Ratio }\end{array}$ \\
\hline Teaching staff & 300 & 75 & 75 & 60 & 56 & $\% 93.3$ \\
\hline Administrator & 280 & 70 & 70 & 52 & 42 & $\% 80.8$ \\
\hline Total & 580 & 145 & 145 & 112 & 98 & $\% 87.5$ \\
\hline
\end{tabular}

\subsection{The Study Tool}

The researcher reference to the relevant studies and researches and a number of tools and references that interested in role of the universities in the local community, view to designing a questionnaire of study for the purposes of collecting information and data, the tool consisted of (45) items distributed on three axes represented by (the university's reputation, the university's policy toward the community, and interaction with the community). After completion of design the study tool was measured the tool sincerity and its reliability, as follows:

\section{a. Tool Sincerity}

Has been verified the Face Validity of the study tool (questionnaire), and through the presentation on five arbitrators with expertise and knowledge from teaching faculty members at Jordanian universities, in the terms of reference of administrative sciences, and was the aim of the arbitration verify the extent of items belonging to the study variables, an appropriate degree of drafting items Linguistically, where been modification reworded drafting some of items.

\section{b. Tool Reliability}

Having been assured of the study tool validity and the readiness of its application, on the study sample of (98) faculty member, and for the purpose of verifying of the internal consistency of the questionnaire items of the study variables, the researcher used for this purpose (Cronbach's alpha) coefficient to measure the (internal consistency of the questionnaire items), which equals to the total tool (0.967), and this value is very good for the administrative and humanitarian researches. As shown in the following Table (2):

Table2. Results of reliability (Internal Consistency of the items)

\begin{tabular}{|l|c|c|c|c|}
\hline No. & The Variables & No. of Items & Cronbach's Alpha & Stability Ratio \\
\hline 1 & The university's reputation & 15 & 0.942 & $\% 94.2$ \\
\hline 2 & The university's policy toward the community & 15 & 0.967 & $\% 96.7$ \\
\hline 3 & Interaction with the community & 15 & 0.876 & $\% 87.6$ \\
\hline- & Overall Tool & $\mathbf{4 5}$ & $\mathbf{0 . 9 6 7}$ & $\mathbf{\% 9 6 . 7}$ \\
\hline
\end{tabular}

In light of the foregoing, the data that were obtained through the application of the study tool, considered valid for the purposes of the statistical analysis and calculation of the statistical indicators for the purpose of answering about the study questions and test its hypotheses.

\section{RESUlTS AND DiscuSSION}

This section devoted to present the results of the statistical analysis of the data subjects' responses of the study sample, which was reached through the use of the Statistical Package for Social Sciences (SPSS), in order to answer the study question and test the hypotheses.

\subsection{Results Related to the Study Question}

\section{What Zarqa University interesting in quality of its services provided to the local community} from the perspective of there employees?

For the purpose of answering on the study question, were account the means, standard deviations, and loadings in order to stand on the estimates of employees in Zarqa University about of their evaluation 
level for degree interest at Zarqa university in the quality of services provided to the local community which are (the university's reputation, university's policy toward the community, and interaction with the community). As shown in the following Table (3):

Table3. Results of Means, Standard Deviations, and Loadings for Variables

\begin{tabular}{|c|c|c|c|c|c|}
\hline No. & Quality of services & Mean & Std. Dev. & Loadings (*) & Rank \\
\hline 1 & The university's reputation & 4.09 & 0.63 & 0.929 & 1 \\
\hline 2 & The university's policy toward the community & 3.98 & 0.73 & 0.911 & 2 \\
\hline 3 & Interaction with the community & 3.74 & 0.46 & 0.752 & 3 \\
\hline
\end{tabular}

(*) The Loadings values calculating by using Factor Analysis

Evident from the results in Table (3), that (The university's reputation) axis get on the (first) rank in terms of its importance for the study sample, with mean was (4.09) and loading of (0.929), and (The university's policy toward the community) axis get on the (second) rank, with mean was (3.98) and loading of (0.911), and finally (The interaction with the community) axis came in (third) rank and the last on the ladder of priorities for the employees in Zarqa University estimates, with mean was (3.74) and loading of (0.752).

\subsection{Results Related to test the Hypotheses}

$\mathbf{H}_{0}$ : There is no statistically significant differences at the significance level $(\alpha \leq 0.05)$, between the employees responses in Zarqa University about quality of its services provided to the local community attributable to some personal and functional characteristics of (sex, specialty of faculty, qualification, and experience years).

To test validity of the study hypothesis of not validity, was used the Independent Samples (t-Test), and One-way analysis of variance (ANOVA). And to achieve this, it should make sure validity of the sub-hypotheses emanating from it or not, as follows:

\subsubsection{Results Related to Test the $1^{\text {st }}$ Sub-hypothesis}

$\mathbf{H}_{01}$ : There is no statistically significant differences at the significance level $(\alpha \leq 0.05)$, between the employees responses in Zarqa University about quality of its services provided to the local community attributable to (gender).

In order to test validity of the $1^{\text {st }}$ sub-hypothesis of not validity, was used the Independent Samples (tTest). It is evident from the means values contained in the Table (4), there existence morphological differences between the means of the employees responses in Zarqa University about the quality of services provided to the local community, according to (gender). To detection of the significance of differences between the means of the employees estimates in Zarqa University about quality of services provided to the local community, due to (gender), was used (t-test) for two independent samples.

Table4. Results of (t-Test), to measure the differences between the employees responses in Zarqa University about quality of its services provided to the local community attributable to (gender)

\begin{tabular}{|c|c|c|c|c|c|}
\hline Variables & Gender & Mean & Std. Dev. & t-value & Sig. \\
\hline The university's & Male & 4.01 & 0.76 & & \\
\cline { 2 - 4 } reputation & Female & 4.20 & 0.33 & -1.465 & 0.146 \\
\hline $\begin{array}{c}\text { The university's } \\
\text { policy toward the } \\
\text { community }\end{array}$ & Male & 3.85 & 0.89 & -1.266 & 0.226 \\
\cline { 2 - 4 } $\begin{array}{c}\text { Interaction with } \\
\text { the community }\end{array}$ & Female & 4.18 & 0.32 & -0.818 & 0.416 \\
\cline { 2 - 4 }
\end{tabular}

Evident from the results listed in Table (4), that there were no statistically significant differences at the significance level $(\alpha=0.05)$, between the employees responses in Zarqa University about the quality of services provided to the local community which are (the university's reputation, the university's policy toward the community, and the interaction with the community), attributable to (gender), which is supported by the calculated values of (t-test) for the mentioned axes, and that the statistical significance values (Sig.) for these axes is greater than the significance level of $(\alpha=0.05)$. This means that the employees responses in Zarqa University about quality of services provided to the local community to be equivalents to have regardless of their sex. This means that will be not rejecting the null sub-hypothesis $\left(\mathrm{H}_{01}\right)$. 


\subsubsection{Results Related to Test the 2nd Sub-hypothesis}

$\mathbf{H}_{02}$ : There is no statistically significant differences at the significance level $(\alpha \leq 0.05)$, between the employees responses in Zarqa University about quality of its services provided to the local community attributable to (specialty the college) variable.

In order to test validity of the $2^{\text {nd }}$ sub-hypothesis of not validity, was used the Independent Samples ( $t$ Test). It is evident from the means values contained in the Table (5), there existence morphological differences between the means of the employees responses in Zarqa University about quality of services provided to the local community, according to (specialty the college). To detection of the significance of differences between the means of the employees estimates in Zarqa University about quality of services provided to the local community, due to (specialty the college), was used (t-test) for two independent samples.

Table5. Results of (t-Test), to measure the differences between the employees responses in Zarqa University about quality of its services provided to the local community attributable to (specialty the college)

\begin{tabular}{|c|c|c|c|c|c|}
\hline Variables & Specialty the College & Mean & Std. Dev. & t-value & Sig. \\
\hline The university's & Scientific & 4.15 & 0.49 & & \multirow{2}{*}{0.982} \\
\cline { 2 - 4 } reputation & Humanity & 4.02 & 0.76 & 0.329 \\
\hline $\begin{array}{c}\text { The university's } \\
\text { policy toward the } \\
\text { community }\end{array}$ & Scientific & 3.99 & 0.71 & \multirow{2}{*}{0.139} & 0.890 \\
\cline { 2 - 4 } $\begin{array}{c}\text { Interaction with } \\
\text { the community }\end{array}$ & Humanity & 3.97 & 0.77 & & \\
\cline { 2 - 4 } & Scientific & 3.78 & 0.45 & 0.861 & 0.392 \\
\hline
\end{tabular}

Evident from the results listed in Table (5), that there were no statistically significant differences at the significance level $(\alpha=0.05)$, between the employees responses in Zarqa University about quality of services provided to the local community which are (the university's reputation, the university's policy toward the community, and the interaction with the community), attributable to (specialty the college), which is supported by the calculated values of (t-test) for the mentioned axes, and that the statistical significance values (Sig.) for these axes is greater than the significance level of $(\alpha=0.05)$. This means that the employees responses in Zarqa University about quality of services provided to the local community to be equivalents to have regardless of their specialty the college. This means that will be not rejecting the null sub-hypothesis $\left(\mathrm{H}_{02}\right)$.

\subsubsection{Results Related to Test the 3rd Sub-hypothesis}

$\mathbf{H}_{03}$ : There is no statistically significant differences at the significance level $(\alpha \leq 0.05)$, between the employees responses in Zarqa University about quality of its services provided to the local community attributable to (qualification).

In order to test validity of the $3^{\text {rd }}$ sub-hypothesis of not validity, was used One-way analysis of variance (ANOVA). It is evident from the means values contained in the Table (6), there existence morphological differences between the means of the employees responses in Zarqa University about quality of services provided to the local community, according to (qualification). To detection of the significance of differences between the means of the employees estimates in Zarqa University about quality of services provided to the local community, due to (qualification), was used One-way (ANOVA).

Table6. Results of (ANOVA), to measure the differences between the employees responses in Zarqa University about quality of its services provided to the local community attributable to (qualification)

\begin{tabular}{|c|c|c|c|c|c|}
\hline Variables & Qualification & Mean & Std. Dev. & $F_{\text {ratio }}$ & Sig. \\
\hline \multirow{3}{*}{$\begin{array}{l}\text { The university's } \\
\text { reputation }\end{array}$} & Diploma & 4.10 & 0.52 & \multirow{3}{*}{0.043} & \multirow{3}{*}{0.958} \\
\hline & Bachelor of & 4.11 & 0.31 & & \\
\hline & Postgraduate & 4.07 & 0.76 & & \\
\hline \multirow{3}{*}{$\begin{array}{l}\text { The university's } \\
\text { policy toward the } \\
\text { community }\end{array}$} & Diploma & 4.33 & 0.32 & \multirow{3}{*}{3.048} & \multirow{3}{*}{0.051} \\
\hline & Bachelor of & 4.05 & 0.47 & & \\
\hline & Postgraduate & 3.85 & 0.87 & & \\
\hline \multirow{3}{*}{$\begin{array}{l}\text { Interaction with the } \\
\text { community }\end{array}$} & Diploma & 3.69 & 0.48 & \multirow{3}{*}{0.389} & \multirow{3}{*}{0.679} \\
\hline & Bachelor of & 3.81 & 0.28 & & \\
\hline & Postgraduate & 3.73 & 0.52 & & \\
\hline
\end{tabular}


It is evident from the results contained in the table (6), that there were no statistically significant differences at the significance level $(\alpha=0.05)$, between the employees responses in Zarqa University about quality of services provided to the local community which are (the university's reputation, the university's policy toward the community, and the interaction with the community), attributable to (qualification), which is supported by the calculated values of (F ratio) for the mentioned axes, and that the statistical significance values (Sig.) for these axes is greater than the significance level of $(\alpha=$ 0.05). This means that the employees responses in Zarqa University about quality of services provided to the local community to be equivalents to have regardless of their of their qualifications. This means that will be not rejecting the null sub-hypothesis $\left(\mathrm{H}_{03}\right)$.

\subsubsection{Results Related to Test the 4th Sub-hypothesis}

$\mathbf{H}_{04}$ : There is no statistically significant differences at the significance level $(\alpha \leq 0.05)$, between the employees responses in Zarqa University about quality of its services provided to the local community attributable to (experience years).

In order to test validity of the $4^{\text {th }}$ sub-hypothesis of not validity, was used One-way analysis of variance (ANOVA). It is evident from the means values contained in the Table (7), there existence morphological differences between the means of the employees responses in Zarqa University about quality of services provided to the local community, according to (experience years). To detection of the significance of differences between the means of the employees estimates in Zarqa University about quality of services provided to the local community, due to (experience years), was used Oneway (ANOVA).

Table7. Results of (ANOVA), to measure the differences between the employees responses in Zarqa University about quality of its services provided to the local community attributable to (experience years)

\begin{tabular}{|c|c|c|c|c|c|}
\hline Variables & Experience Years & Mean & Std. Dev. & $\mathbf{F}_{\text {ratio }}$ & Sig. \\
\hline \multirow{3}{*}{$\begin{array}{c}\text { The university's } \\
\text { reputation }\end{array}$} & Less than 10 years & 4.06 & 0.83 & \multirow{3}{*}{1.414} & \multirow{3}{*}{0.248} \\
\hline & $10-15$ & 3.95 & 0.50 & & \\
\hline & 15 year and more & 4.19 & 0.79 & & \\
\hline \multirow{3}{*}{$\begin{array}{l}\text { The university's } \\
\text { policy toward the } \\
\text { community }\end{array}$} & Less than 10 years & 4.01 & 0.10 & \multirow{3}{*}{7.679} & \multirow{3}{*}{0.001} \\
\hline & $10-15$ & 3.61 & 0.77 & & \\
\hline & 15 year and more & 4.22 & 0.75 & & \\
\hline \multirow{3}{*}{$\begin{array}{l}\text { Interaction with } \\
\text { the community }\end{array}$} & Less than 10 years & 3.69 & 0.29 & \multirow{3}{*}{13.125} & \multirow{3}{*}{0.000} \\
\hline & $10-15$ & 3.47 & 0.30 & & \\
\hline & 15 year and more & 3.95 & 0.51 & & \\
\hline
\end{tabular}

It is evident from the results listed in the Table (7), that:

a. There were no statistically significant differences at the significance level $(\alpha=0.05)$, between the employees responses in Zarqa University about quality of services provided to the local community of (the university's reputation), attributable to (experience years), which is supported by the calculated value of ( $F$ ratio) for the mentioned axes, and that the statistical significance value (Sig.) for this axes is greater than the significance level of $(\alpha=0.05)$. This means that the employees responses in Zarqa University about quality of services provided to the local community to be equivalents to have regardless of their experience years.

b. There exist statistically significant differences at the significance level $(\alpha=0.05)$, between the employees responses in Zarqa University about quality of services provided to the local community of (the university's policy towards the community, and interaction with the community), attributable to (experience years), which is supported by the calculated values of ( $\mathrm{F}$ ratio) for the mentioned axes, and that the statistical significance values (Sig.) $(0.000,0.001)$ respectively, for these axes is less than the significance level of $(\alpha=0.05)$. This means that the employees responses in Zarqa University about quality of services provided to the community are not disproportionate among them. And these differences was in favor of experience years class (15 years and over) about the mentioned two axes in terms of there means (4.22) and (3.95) respectively, and the two means are greater than the categories means of the other (experience years) for the mentioned two axes. This means that will be reject of the null sub-hypothesis $\left(\mathrm{H}_{04}\right)$. 


\section{CONCLUSIONS AND RECOMMENDATIONS}

\subsection{Conclusions}

The study concluded a number of conclusions in light of its results, among them the following:

a. The results indicated that (the university's reputation) axis get on the (first) rank in terms of its importance for members of the study sample, and the axis (the university's policy toward the community) came in the (second) rank, and finally the axis (the interaction with the community) came in the (third) rank on the priorities of the employees estimates in Zarqa University.

b. There were no statistically significant differences at the significance level $(\alpha=0.05)$, between the employees responses in Zarqa University about quality of services provided to the local community which are (the university's reputation, the university's policy toward the community, and the interaction with the community), attributable to (gender).

c. There were no statistically significant differences at the significance level $(\alpha=0.05)$, between the employees responses in Zarqa University about quality of services provided to the local community which are (the university's reputation, the university's policy toward the community, and the interaction with the community), attributable to (specialty the college).

d. There were no statistically significant differences at the significance level $(\alpha=0.05)$, between the employees responses in Zarqa University about quality of services provided to the local community which are (the university's reputation, the university's policy toward the community, and the interaction with the community), attributable to (qualification).

e. There were no statistically significant differences at the significance level $(\alpha=0.05)$, between the employees responses in Zarqa University about quality of services provided to the local community of (the university's reputation), attributable to (experience years)

f. There exist statistically significant differences at the significance level $(\alpha=0.05)$, between the employees responses in Zarqa University about quality of services provided to the local community of (the university's policy towards the community, and interaction with the community), attributable to (experience years). And these differences was in favor of experience years class ( 15 years and over) about the mentioned two axes in terms of there means.

\subsection{Recommendations}

The study reached a number of recommendations in light of its results, among them the following:

a. Necessity focus on of Zarqa University on (the interaction with the community) axis, due to obtaining on the (third) rank and last on the ladder priorities of the employees estimates in the mentioned university.

b. Work on holding workshops for newly recruited employees from teaching and administrative staff in order to emphasize the importance of the quality of its services provided to the local community of the two mentioned (the university's policy toward the community, interact with the community).

c. The study suggests that a similar studies in the future, on the universities or the academy is focused on other axes bodies, taking into account work compared for the studies results that are conducted.

\section{REFERENCES}

[1] Al-Tall, Wael Abdul Rahman and Sarayreh, Khaled (2013), Degree of interest in Mutah University of quality and its role in serving the local community in light of the estimates of the faculty members in university, Mutah University, Mutah Journal for Research and Studies.

[2] Aly, N, A Kpovi, J. (2001).Total quality management In California Public Higher Education, Quality Assurance in Education.

[3] Ar-Rawashdeh, Ola Zuhair (2011), Role of the university in community service from the viewpoint of the faculty members in relation to some personal variables have, Balqa University model, magazine or villages Social Sciences. management universities, visions of sustainable development, Dar subscription for publication and distribution, Cairo.

[4] Ar-Rasheed, Muhammad Ahmad, (2005), Role of the university in the community service and the extent of Qilm universities Alornah this role, $\mathrm{PhD}$ Thesis unpublished, Amman League of Arab Studies, Amman. 
[5] Barakat, Abdullah (2003), Impact of the application of total quality Alim on education systems in the Jordan field study, (unpublished research).

[6] Basinger, J.(2000). Report on The Plan of using the (100) Million \$ Gift former Netscape Communications Corp. 21(46), J. A. 4.

[7] Bdh, Ahmed (2003), Model proposed for the management of quality of the comprehensive quality in the Jordanian Public universities, Journal of Arab Universities Union.

[8] Dradkeh, Amjad (2004), Degree of application of the total quality management at Al-Balqa University from the perspective of the educational leaders, Master Thesis (unpublished), AlYarmouk University, Jordan.

[9] Hariand, Kirk, (2001), Identifying Baldrige based school Quality improvement strategies in 1998-1999, Ph.D. Dissertation, Published by Internet, Texas University.

[10] Hernandez, Rolando, (2001), Total Quality Management in Higher Education: The application of T.Q.M in Texas School District, Ph.D. Dissertation, Published by Internet, University of Austin.

[11] Khalil, Ahmed Ibrahim, and Zuhairi (2001), Quality Management in Education: foreign experiences and the possibility to utilize them, Department of Education Conference in the Arab world in the information age, Egyptian Society of Comparative Education and Educational Administration, Ain Shams University, Cairo.

[12] Kolcinski Johon, (2002), Evaluation of success and failure factors and criteria in Implementation of Total Quality Management Principles in Administration at selected Institution of Higher.

[13] Pissed, Mohammed, (2003), about a contemporary vision of the functions of the universities, in light of future challenges, Dar Al Huda for printing, Cairo.

[14] Schumaker a \& wood, (2001), Role of college in a university wide approach to community partnership: the university of Nebraska at Omaha experience an international forum, 12(4): 6679.

[15] Tiamiya, M. F. and Bailey (2001), Human services for the elderly and the role of the university community collaboration: perceptions of human service agency Workers educational gerontology. No. 6.

\section{AUTHORS' BIOGRAPHY}

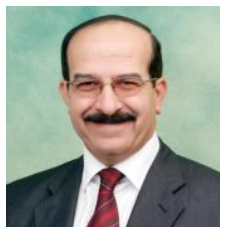

Majid Abdul-Mahdi Mesaadah, Associate Professor of Business Administration at Faculty of Economics and Administrative Sciences of Zarqa University in Jordan, he teaches and achieves the researches in Business Administration. He took his BA in Business Management at (1985), Master Degree in Business Management (2001), and his Ph.D. in Business Administration (2008) from Sudan- University Technology \& Sciences. He is the author of (10) books and (25) article, and study about the following subjects and fields: Total Quality Management, Human Resources Management, Leadership, and Organizational Behavior. 